\title{
ВМІСТ ПРОДУКТІВ ЛІПОПЕРОКСИДАЦІЇ ТА АКТИВНІСТЬ ЕНЗИМІВ АНТИОКСИДАНТНОЇ СИСТЕМИ В МІОКАРДІ У ДИНАМІЦІ ФОРМУВАННЯ ЕКСПЕРИМЕНТАЛЬНОГО ПАРОДОНТИТУ
}

Вступ. Розвиток пародонтиту супроводжується змінами маркерів вільнорадикального окиснення та антиоксидантної системи в міокарді, які поступово запускають процеси пероксидного окиснення ліпідів і компенсаторно стимулюють активність досліджуваних ензимів з наступною депресією антиоксидантного захисту. Ці порушення проявляються різною мірою і мають неоднакову спрямованість, що свідчить про різноманітні механізми розвитку запального процесу в пародонті.

Мета дослідження - визначити вміст продуктів ліпопероксидації та активність ензимів антиоксидантної системи в міокарді у динаміці формування експериментального пародонтиту.

Методи дослідження. Досліди проведено на 45 нелінійних білих щурах-самцях масою 0,17-0,21 ка, яких поділили на п'ять груп (по 9 тварин у кожній): 1-ша - контрольна; 2-га, 3-тя, 4-та і 5-та - тварини з експериментальним пародонтитом, відповідно, на 1-шу, 7-му, 10-ту і 17-ту доби експерименту.

Результати й обговорення. Результати біохімічних досліджень свідчать про те, що на 1-шу, 7-му, 10-ту і 17-ту доби фрормування експериментального пародонтиту збільшувався вміст у міокарді дієнових кон'югатів та малонового діальдегіду, що вказувало на активацію процесів вільнорадикального окиснення. Крім порушень прооксидантної системи, досліджували особливості змін антиоксидантного захисту за показниками активності супероксиддисмутази, каталази, вмісту церулоплазміну в міокарді у динаміці формування експериментального пародонтиту. Встановлено, що на 1-шу добу експерименту ці показники підвищувалися, на 7-му - не змінювалися, на 10-ту і 17-ту доби - знижувалися в динаміці фрормування пародонтиту.

Висновок. Визначення маркерів вільнорадикального окиснення (дієнових кон'югатів, малонового діальдегіду) та антиоксидантної системи (супероксиддисмутази, каталази, церулоплазміну) в міокарді показало поступову стимуляцію процесів пероксидного окиснення ліпідів і компенсаторне підвищення активності досліджуваних ензимів з наступною депресією антиоксидантного захисту, особливо на 10-ту і 17-ту доби фрормування пародонтиту, що вказує на розвиток оксидативного стресу.

КЛЮЧОВІ СЛОВА: експериментальний пародонтит; ліпопероксидація; антиоксидантна система.

ВСТУП. Дистрофрічно-запальні захворювання пародонта є найбільш поширеною патологією в стоматології. Генералізований пародонтит характеризується різноманітними проявами клінічної картини хвороби в окремих пацієнтів й у динаміці патологічного процесу в пародонті у кожного хворого [1]. Розвиток генералізованого пародонтиту слід розглядати як результат взаємодії мікробного чинника й організму хворого. На даний час різнобічно вивчено роль мікробного, травматичного, імунного, судинного та інших місцевих фракторів у розвитку цього захворювання. 3 одного боку, перебіг місцевої запальної реакції залежить від імунобіологічних властивостей організму даного пацієнта, з іншого - вогнище запалення в тканинах пародонта впливає на цілий організм. Виникає замкнуте коло, що погіршує репарацію ушкодження тканин с О. Т. Городецький, М. С. Регеда, 2019. і відновлення гомеостазу [2]. Однією з причин відсутності стійкого ефекту після проведеної терапії 3 приводу пародонтиту можуть бути як дисбіотичні явища в порожнині рота з порушенням стабільності нормальної мікрофрлори, так і зміни реактивності організму в цілому. Цьому сприяють зростання агресивності навколишнього середовища, вплив стресорних фракторів, збільшення серед населення кількості осіб 3 різними імунодефіцитами, нераціональне застосування антибіотиків [3]. Можливо, комплексна терапія генералізованого пародонтиту, яка включає використання антимікробних засобів із широким спектром дії, сприяє тотальному пригніченню ендогенної мікрофллори порожнини рота й усіх ланок захисту [4]. Зокрема, впродовж останніх десятиліть особливу увагу приділяють одному з важливих молекулярних механізмів ушкодження клітин, що охоплюють процеси 
пероксидного окиснення ліпідів і антиоксидантну систему при пародонтиті.

Мета дослідження - визначити вміст продуктів ліпопероксидації та активність ензимів антиоксидантної системи в міокарді у динаміці фрормування експериментального пародонтиту.

МЕТОДИ ДОСЛІДЖЕННЯ. Досліди проведено на 45 нелінійних білих щурах-самцях масою 0,17-0,21 кг, яких поділили на п'ять груп (по 9 тварин у кожній): 1-ша -контрольна; 2-га, 3-тя, 4-та і 5-та - тварини з експериментальним пародонтитом, відповідно, на 1-шу, 7-му, 10-ту і 17-ту доби експерименту. Відтворювали модель експериментального генералізованого пародонтиту за методом О. І. Сукманського й О. А. Макаренка шляхом використання модифікованої дієти для щурів м'якої консистенції з високим вмістом вуглеводів [5]. Тварин з пародонтитом виводили з експерименту на 1-шу, 7-му, 10-ту і 17-ту доби під налбуфріновим наркозом (вводили внутрішньочеревно у дозі 182 мг/кг маси тіла щура), забирали тканини міокарда для біохімічних досліджень. Цей експеримент було проведено згідно з принципами біоетики відповідно до положень Європейської конвенції про захист хребетних тварин, що використовуються для дослідних та інших наукових цілей (Страсбург, 1986), Директиви Ради Європи 2010/63/EU, Закону України № 3447-IV “Про захист тварин від жорстокого поводження", загальних етичних принципів експериментів на тваринах, ухвалених на Першому національному конгресі України 3 біоетики Львівського національного медичного університету імені Данила Галицького (протокол № 4 від 18 січня 2017 р.). Вміст дієнових кон'ю- гатів (ДК) визначали за методом В. Б. Гаврилова [6], малонового діальдегіду (МДА) - за методом Е. Н. Коробейникової [7], супероксиддисмутази (СОД) - за методом R. Fried [8], каталази (КТ) за методом R. Holmes [9], церулоплазміну (ЦП) за методом В. Г. Колб, В. С. Камишникова [10]. Одержані цифррові результати було опрацьовано статистично методом Стьюдента.

РЕЗУЛЬТАТИ Й ОБГОВОРЕННЯ. РеЗУЛЬТаТИ біохімічних досліджень свідчать про те, що на 1-шу, 7-му, 10-ту і 17-ту доби фрормування експериментального пародонтиту збільшувався вміст у міокарді дК, відповідно, на 45,2 \% $(p<0,05), 46,6 \%(p<0,05), 47,8 \%(p<0,05), 59,2 \%$ $(p<0,05)$ проти контрольної групи тварин (рис.). Визначення іншого показника пероксидного окиснення ліпідів - малонового діальдегіду в міокарді показало аналогічний напрямок порушень. Він підвищувався на 37,1 \% (p<0,05), $37,3 \%(p<0,05), 38,4 \%(p<0,05), 39,6 \%(p<0,05)$, відповідно, на 1-шу, 7-му, 10-ту і 17-ту доби пародонтиту відносно контрольної групи, що вказувало на активацію процесів вільнорадикального окиснення (рис.). Таким чином, дослідження маркерів вільнорадикального окиснення в динаміці формування кардіоміопатії показало поступову стимуляцію процесів пероксидного окиснення ліпідів. Крім порушень прооксидантної системи, досліджували особливості змін антиоксидантного захисту за показниками активності СОД, КТ, вмісту ЦП у міокарді в динаміці орормування експериментального пародонтиту. Встановлено, що на 1-шу добу експерименту активність СОД зростала на 36,4 \% $(p<0,05)$, на 7-му - не зазнавала змін, а на 10-ту і 17-ту доби -

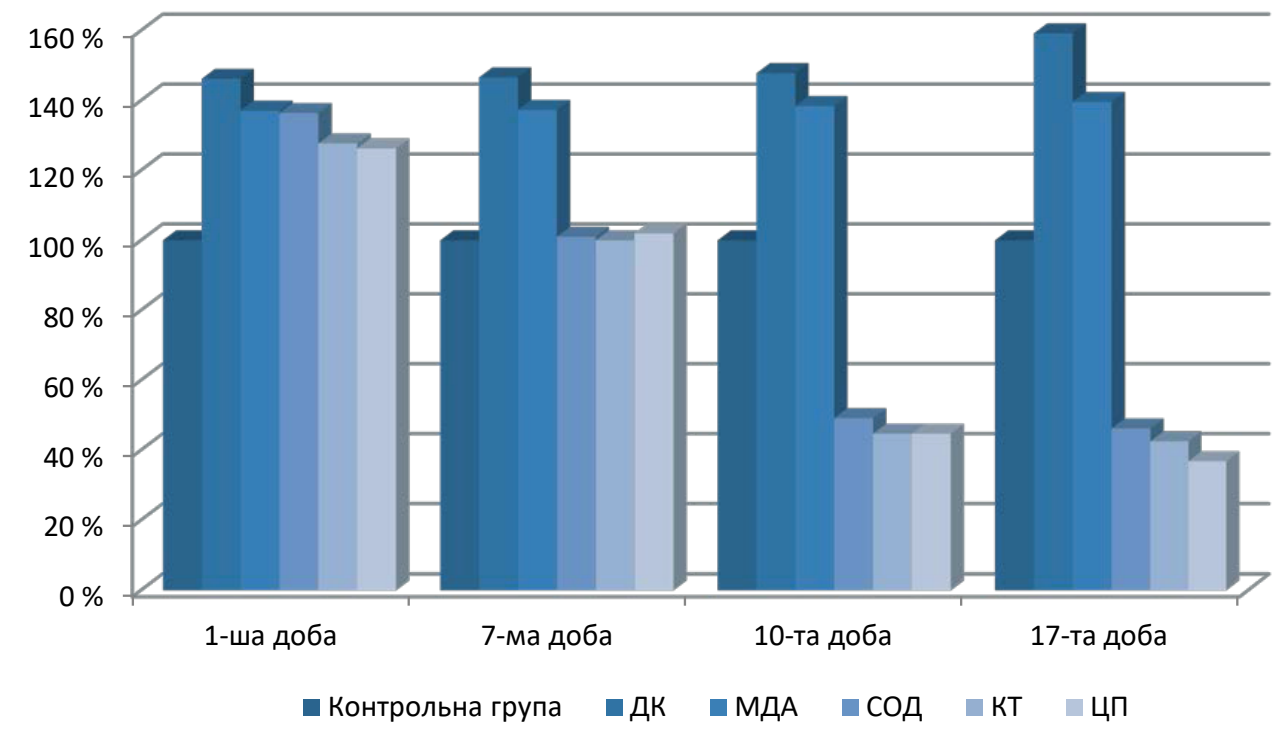

Рис. Вміст продуктів ліпопероксидації та активність ензимів антиоксидантної системи в міокарді при пародонтиті (\% порівняно з контролем). 
знижувалася, відповідно, на 50,9 \% $(p<0,05)$ та $53,8 \%(p<0,05)$ проти 1-ї групи тварин. Аналогічно змінювалась активність КТ, яка на 1-шу добу підвищувалася на 27,6 \% (p<0,05), на 7-му - не змінювалася, а на 10-ту і 17-ту доби - знижувалася на 57,5 \% $(p<0,05)$ відносно контрольної групи білих щурів-самців (рис.). Вміст ЦП на 1-шу добу збільшувався на 26,3% (p<0,05), на 7-му перебував на рівні 1-ї групи, а далі зменшувався на 55,3\% $(p<0,05)$ та 63,2 \% (p<0,05), відповідно, на 10-ту і 17-ту доби порівняно з контрольною групою (рис.).

Отже, дослідження маркерів прооксидантно-антиоксидантної системи в міокарді показало постійне нагромадження продуктів ліпопероксидації на тлі виснаження як фрерментативних, так і неферментативних ланок антиоксидантної

\section{СПИСОК ЛІТЕРАТУРИ}

1. Данилевский Н. Ф. Заболевания пародонта / Н. Ф. Данилевский, А. В. Борисенко. - К. : Здоров'я, 2000. -461 c.

2. Иммунокоррекция при воспалительных заболеваниях пародонта / А. И. Рыбаков, В. Н. Исаев, Т. П. Иванюшко [и др.] // Иммунология. -1996. - № 6. С. $57-59$.

3. Левицкий А. П. Лизоцим вместо антибиотиков / А. П. Левицкий. - Одесса, 2005. - 74 с.

4. Грудянов А. И. Применение таблетированных форм пробиотиков бифидумбактерина и ацелакта в комплексном лечении воспалительных заболеваний пародонта / А. И. Грудянов, Н. А. Дмитриева, Е. В. Фоменко // Стоматология. - 2002. - № 1. - С. 39-43.

5. Сукманський О. І. Експериментальна модель генералізованого пародонтиту / О.І.Сукманський, О. А. Макаренко // Вісн. стоматології. - 2006. - № 2. C. 2-3.

\section{REFERENCES}

1. Danilevskiy, N.F., \& Borisenko, A.V. (2000). Zabolevaniya parodonta [Diseases of the periodontal disease]. Kyiv: Zdorovia [in Russian].

2. Rybakov, A.I., Isaev, V.N., \& Ivanushushko, T.P. (1996). Immunokorektsiya pri vospalitelnykh zabolevaniyakh parodonta [Immunocorrection in inflammatory diseases of periodontal disease]. Immunologiya - Immunology, 6, 57-59 [in Russian].

3. Levitskyy, A.P. (2005). Lyzotsym vmesto antybiotykov [Lysozyme instead of antibiotics]. Odesa [in Russian]

4. Grudyanov, A.I., Dmitrieva, N.A., \& Fomenko, E.V. (2002). Primeneniya tabletovanykh form probiotikov системи в міокарді, що свідчило про порушення рівноваги пероксидного окиснення ліпідів та антиоксидантної системи і розвиток оксидативного стресу, який посилює перебіг запального процесу в організмі тварин.

ВИСНОВОК. Визначення маркерів вільнорадикального окиснення (дієнових кон'югатів, малонового діальдегіду) та антиоксидантної системи (супероксиддисмутази, каталази, церулоплазміну) в міокарді показало поступову стимуляцію процесів пероксидного окиснення ліпідів і компенсаторне зростання активності досліджуваних ензимів з наступною депресією антиоксидантного захисту, особливо на 10-ту і 17-ту доби формування пародонтиту, що вказує на розвиток оксидативного стресу.

6. Гаврилов В. Б. Спектросотометрическое определение содержания гидроперекисей липидов в плазме крови / В. Б. Гаврилов, М.И.Мишкорудная // Лабораторная диагностика ишемической болезни сердца. - К. : Здоров'я, 1989. - С. 170-171.

7. Коробейникова Э. Н. Модифрикация определения продуктов ПОЛ в реакции с тиобарбитуровой кислотой / Э. Н. Коробейникова // Лаб. дело. - 1989. № 7. - C. 8-10.

8. Fried R. Enzymatik and non-enzymatic assay of superoxide / R. Fried // Biochemie. - 1975. - 57, No. 5. P. 657-660.

9. Holmes R. Epigenetic interconversions of the multiple forms of mouse liver catalase. FEBS Lett. 1970. - 11, No. 11. - P. 45-48.

10. Колб В. Г. Определение активности церулоплазмина в крови : справочник по клинич. химии / В. Г. Колб, В. С. Камышников. - Минск : Беларусь, 1982. - C. 290-291.

bifidymbakterina i atselakta $v$ kompleksnom lechenii vospalitelnykh zabolevaniy parodonta [Application of tableted forms of probiotics of bifidumbacterin and acetalact in the complex treatment of inflammatory periodontal diseases]. Stomatologiya - Dentistry, 1, 39-43 [in Russian].

5. Sukmanskyi, O.I., \& Makarenko, O.A. (2006). Eksperementalna model heneralizovanoho parodontytu [Experimental model of generalized periodontitis]. Visnyk stomatolohii - Herald of Dentistry, 2, 2-3 [in Ukrainian].

6. Gavrilov, V.B., \& Mishrudnaya, M.I. (1989) Spektrofotometricheskoye opredeleniye soderzhaniye gidroperekisey lipidov v plazme krovi [Spectrophotomet- 
ric determination of the content of lipid hydroperoxides in blood plasma]. Laboratornaya diagnostika ishemicheskoy bolezni serdtsa - Laboratory Diagnosis of Coronary Heart Disease, 170-171 [in Russian].

7. Korobeynikova, Ye.N. (1989). Modifikatsiya opredeleniya produktov $\mathrm{POL} v$ reaktsii c tiobarbiturovoy kislotoy [Modification of the definition of the products of the LPO in reaction with thiobarbituric acid]. Laborotornoye delo - Laboratory Case, 7, 8-10 [in Russian].
8. Fried, R. (1975). Enzymatik and non-enzymatic assay of superoxide. Biochemie, 57 (5), 657-660.

9. Holmes, R. (1970). Epigenetic interconversions of the multiple forms of mouse liver catalase. FEBS Lett, 11 (11), 45-48.

10. Kolb, V.G., \& Kamishnikov, V.S. (1982). Opredeleniye aktivnosti tsereloplazmina v krovi: spravochnik po klin. khimii [Determination of the activity of ceruloplasmin in the blood: reference book on clinical chemistry]. Minsk: Belarus [in Russian].

\author{
О. Т. Городецкий, М. С. Регеда \\ ЛЬВОВСКИЙ НАЦИОНАЛЬНЫЙ МЕДИЦИНСКИЙ УНИВЕРСИТЕТ ИМЕНИ ДАНИЛА ГАЛИЦКОГО
}

\title{
СОДЕРЖАНИЕ ПРОДУКТОВ ЛИПОПЕРОКСИДАЦИИ И АКТИВНОСТЬ ЭНЗИМОВ АНТИОКСИДАНТНОЙ СИСТЕМЫ В МИОКАРДЕ В ДИНАМИКЕ ФОРМИРОВАНИЯ ЭКСПЕРИМЕНТАЛЬНОГО ПАРОДОНТИТА
}

\section{Резюме}

Вступление. Развитие пародонтита сопровождается изменениями маркеров свободнорадикального окисления и антиоксидантной системы в миокарде, которые постепенно запускают процессы перекисного окисления липидов и компенсаторно стимулируют активность исследуемых энзимов с последующей депрессией антиоксидантной защиты. Эти нарушения проявляются в разной степени и имеют неодинаковую направленность, что свидетельствует о разнообразных механизмах развития воспалительного процесса в пародонте.

Цель исследования - определить содержание продуктов липопероксидации и активность энзимов антиоксидантной системы в миокарде в динамике фрормирования экспериментального пародонтита.

Методы исследования. Опыты проведены на 45 нелинейных белых крысах-самцах массой 0,17-0,21 к2, которых разделили на пять групп (по 9 животных в каждой): 1-я - контрольная; 2-я, 3-я, 4-я и 5-я - животные с экспериментальным пародонтитом, соответственно, на 1-е, 7-е, 10-е и 17-е сутки эксперимента.

Результаты и обсуждение. Результаты биохимических исследований свидетельствуют о том, что на 1-е, 7-е, 10-е и 17-е сутки фрормирования экспериментального пародонтита увеличивалось содержание в миокарде диеновых конъюгатов и малонового диальдегида, что указывало на активацию процессов свободнорадикального окисления. Кроме нарушений прооксидантной системы, исследовали особенности изменений антиоксидантной защиты по показателям активности супероксиддисмутазы, каталазы, содержания церулоплазмина в миокарде в динамике фрормирования экспериментального пародонтита. Установлено, что на 1-е сутки эксперимента эти показатели повышались, на 7-е - не менялись, на 10-е и 17-е сутки - снижались в динамике формирования пародонтита.

Вывод. Определение маркеров свободнорадикального окисления (диеновых конъюгатов, малонового диальдегида) и антиоксидантной системы (супероксиддисмутазы, каталазы, церулоплазмина) в миокарде показало постепенную стимуляцию процессов перекисного окисления липидов и компенсаторное повышение активности исследуемых энзимов с последующей депрессией антиоксидантной защиты, особенно на 10-е и 17-е сутки фрормирования пародонтита, что указывает на развитие оксидативного cmpecca. система

КЛЮЧЕВЫЕ СЛОВА: экспериментальный пародонтит; липопероксидация; антиоксидантная 


\section{CONTENT OF PRODUCTS OF LIPOPEROXIDATION AND ACTIVITY OF THE ANTIOXIDANT SYSTEM IN MYOCARDIUM IN THE DYNAMICS OF FORMATION OF EXPERIMENTAL PERIODONTITIS}

\section{Summary}

Introduction. Development of periodontitis is accompanied by changes in markers of free radical oxidation and antioxidant system in the myocardium, which gradually trigger the processes of lipid peroxidation and compensatorily stimulate the activity of the enzymes studied, followed by depression of antioxidant defense. These violations are manifested in varying degrees and vary in direction, which indicates a variety of mechanisms of development of inflammation in the periodontal disease.

The aim of the study - to find out the content of lipid peroxidation products and antioxidant enzyme activity in the myocardium system dynamics formation of experimental periodontitis.

Research Methods. Experiments were carried out on 45 non-linear white rats, males; group 1 - control, groups 2, 3, 4 and 5-group of animals with experimental periodontitis according to the 1st, 7th, 10th and 17th days of the experiment.

Results and Discussion. The results of biochemical studies found that on the 1st, 7th, 10th and 17th days of the formation of experimental periodontitis, there was an increase in the content of myocardium of diene conjugates, malonic dialdehyde, indicating the activation of processes free radical oxidation. Together with the study of violations of the prooxidant system, the peculiarities of changes in antioxidant defense were studied in terms of the activity of superoxide dismutase, catalase, and the content of ceruloplasmin indices in the myocardium in the dynamics of the formation of experimental periodontitis. It is established that these indices increase on the 1st day of the experiment, at the 7th day they do not change and at the 10th and 17th days their significance in the dynamics of periodontitis decreases.

Conclusion. Determination of the markers of free radical oxidation (diene conjugates and malonic dialdehyde) and antioxidant system (superoxide dismutase, catalase, ceruloplasmin) in the myocardium showed a gradual stimulation of lipid peroxidation processes and compensatory growth of activity of the investigated enzymes with subsequent depression of antioxidant defense, especially on the 10th and 17th days of the formation of periodontitis, which indicates the development of oxidative stress.

KEY WORDS: experimental periodontitis; lipid peroxidation; antioxidant system.

Отримано 26.04.19

Адреса для листування: М. С. Регеда, Львівський національний медичний університет імені Данила Галицького, вул. Пекарська, 69, Львів, 79010, Україна, e-mail: Ivivmedinst@gmail.com. 